\title{
Modelling nitrogen transport in sugar cane from soil to runoff from banded surface and buried fertiliser using HYDRUS2D and a post-processing algorithm
}

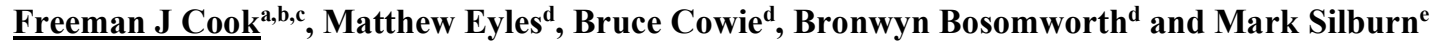 \\ ${ }^{a}$ Freeman Cook \& Associates, ${ }^{b}$ The University of Queensland School of Food and Agriculture, ${ }^{c}$ Griffith \\ University Australian Rivers Institute, ${ }^{d}$ Queensland Dept of Natural Resources, Mines and Energy \\ Rockhampton, ${ }^{e}$ Queensland Dept of Natural Resources, Mines and Energy, Toowoomba
} Email: Freeman.j.cook@gmail.com

\begin{abstract}
Simulated rainfall was applied to sugar cane at the Macknade Research Station, Herbert region North Queensland, to determine the loss of nitrogen to runoff for fertiliser placed in a $100 \mathrm{~mm}$ wide strip on raised beds (spaced $1.8 \mathrm{~m}$ apart and a bed width of $1.2 \mathrm{~m}$ ) applied either on the surface or buried at a depth of 50-150 mm. The sites were covered with shelters between rainfall simulations to avoid rainfall ingress, but evaporation could still take place. Modelling of these experiments was untaken to estimate nitrogen losses from recently fertilised soils
\end{abstract}

Table 1. Modelled (MO) and measured (ME) DIN $\left(\mathrm{NH}_{4}-\mathrm{N}\right.$ and $\mathrm{NO}_{\mathrm{x}}-\mathrm{N}$ ) losses in runoff two fertiliser treatments. Simulations with saturated hydraulic conductivity $(\mathrm{Ks}(1))$ halved are also shown.

\begin{tabular}{|l|l|l|l|l|l|l|l|l|}
\hline \multirow{2}{*}{$\begin{array}{l}\text { Soil } \\
\text { layer 1 }\end{array}$} & \multicolumn{2}{|l|}{ Surface } & \multicolumn{2}{l|}{ Subsoil } \\
\cline { 2 - 9 } & $\begin{array}{l}\mathrm{NH}_{4}-\mathrm{N} \\
\left(\mathrm{kg} \mathrm{ha}^{-1}\right)\end{array}$ & \multicolumn{2}{l|}{$\begin{array}{l}\mathrm{NO}_{\mathrm{x}}-\mathrm{N} \\
\left(\mathrm{kg} \mathrm{ha}^{-1}\right)\end{array}$} & \multicolumn{2}{l|}{$\begin{array}{l}\mathrm{NH}_{4}-\mathrm{N} \\
\left(\mathrm{kg} \mathrm{ha}^{-1}\right)\end{array}$} & \multicolumn{2}{l|}{$\begin{array}{l}\mathrm{NO}_{\mathrm{x}}-\mathrm{N} \\
\left(\mathrm{kg} \mathrm{ha}^{-1}\right)\end{array}$} \\
\hline & $\mathrm{ME}$ & $\mathrm{MO}$ & $\mathrm{ME}$ & $\mathrm{MO}$ & $\mathrm{ME}$ & $\mathrm{MO}$ & $\mathrm{ME}$ & $\mathrm{MO}$ \\
\hline $\mathrm{Ks}(1)$ & 0.73 & 0.09 & 1.32 & 0.98 & 0.12 & 0.03 & 1.39 & 0.84 \\
\hline $\mathrm{Ks}(1) / 2$ & 0.73 & 0.98 & 1.32 & 1.29 & 0.11 & 0.03 & 1.39 & 1.80 \\
\hline
\end{tabular}
in wet tropical catchments. The model parameters can be used to model other possible runoff scenarios. The modelling required a two-dimensional model with multiple solute species transport and chain reaction processes. The HYDRUS2D model (Simunek et al., 2012) was chosen; however, it cannot model the transfer of solutes to the runoff water. An analytical model, which can transfer of solutes to runoff was developed by Wallach and van Genuchten (1990):

$$
J(0, t)=-\theta_{s} k\left[c(t)-c_{r}\right]
$$

where $J(0, \mathrm{t})$ is the flux density of solute transferred from the soil surface to the runoff water $\left[\mathrm{M} \mathrm{L}^{-3} \mathrm{~T}^{-1}\right.$ ] at time $\mathrm{t}[\mathrm{T}], \theta_{s}$ is the saturated volumetric water content at the soil surface $\left[\mathrm{L}^{3} \mathrm{~L}^{-3}\right], k$ is the mass transfer coefficient [ $\left.\mathrm{L} \mathrm{T}^{-1}\right], c(t)$ is the concentration at the soil surface with time $\left[\mathrm{M} \mathrm{L}^{-3}\right]$ and $c_{r}$ is the concentration in the runoff water $\left[\mathrm{M} \mathrm{L}^{-3}\right]$, which we set to zero as Wallach and van Genuchten (1990) did. A post-processing method to compute the solute transport of nitrate, nitrite and ammonium to the runoff using eqn (1) was developed. This required surface concentrations of the solutes with time in a cross-section across the bed $(c(x, t)$ where $x$ is the cross-section distance) and integrating both with space to give the mass transfer at time $t_{i}, M\left(s, t_{i}\right)$, using:

$$
M_{i}\left(s, t_{i}\right)=\int_{0}^{x_{n}}-\theta_{s} c\left(x, t_{i}\right) d x \approx \theta_{s} \sum_{j=0}^{n-1}\left[c\left(x_{j+1}, t_{i}\right)+c\left(x_{j}, t_{i}\right)\right]\left(x_{j+1}-x_{j}\right) / 2, s=\sum_{j=0}^{j-1}\left(x_{j+1}-x_{j}\right)
$$

and this was then integrated with time to give the mass transferred during the runoff:

$$
M_{T}=k \int_{0}^{T} M_{i}\left(s, t_{i}\right)=k \sum_{i=0}^{m-1}\left[M_{i+1}+M_{i}\right]\left(t_{i+1}-t_{i}\right) / 2, T=\sum_{i=0}^{m-1}\left(t_{i+1}-t_{i}\right)
$$

where $s$ is the length of the runoff surface [L]. The parameters in the model were adjusted to obtain the best fit with no fertiliser treatment experimental values. These values were used to model surface-applied and subsurface applied fertiliser. The results are shown in Table 1. The infiltration rate following the first rainfall was halved, so simulations were performed with saturated hydraulic conductivity of layer 1 halved.

Keywords: Runoff, nitrogen, HYDRUS2D, hybrid model 


\section{INTRODUCTION}

Nitrogen loss in the Wet Tropics is ranked as the highest relative risk to Great Barrier Reef water quality with improved nitrogen management identified as a priority to improve water quality (The State of Queensland 2013). In particular, dissolved inorganic nitrogen (DIN), consisting of ammonium, nitrite, and nitrate, is of concern as they are readily bioavailable in the marine environment and can cause algae blooms and have direct and indirect impacts on corals (Wooldridge et al., 2006; D'Angelo and Wiedenmann 2014). Sugar cane is a major crop in the Wet Tropics and $84 \%$ of the anthropogenic DIN lost in runoff from this region has been attributed to fertiliser losses from sugar cane production (Harris, 2001; Waterhouse et al. 2012).

Experiments were carried out in 2014 to measure the nutrient losses in runoff under simulated rainfall at the Macknade research station (Cowie et al. 2013, Melland et al., 2019). The experiments involved treatments of: nil fertilizer; fertiliser applied in a horizontal band on the surface; and, fertiliser applied into the subsoil in a vertical band. Simulated rainfall was applied on three occasions, 7, 20 and 55 days after fertiliser application and lasted until 30 minutes of runoff had occurred. During the runoff, the volume of runoff and runoff samples taken were collected. The experimental design objective was to collect comparative data on the impacts of fertiliser placement on DIN runoff relating to time from application to the first rainfall event, and then subsequent rainfall events.

To extend the data, and estimate the effect of the rainfall shelter, modelling of the nitrogen loss to the runoff water is required. Models that can do the twodimensional solute transport and transfer of solutes to runoff are generally not available. Here we report the development of a hybrid model consisting of a numerical model (HYDRUS2D) to calculate the water and solutes in the soil. From this model we get the solute concentration with time across the soil surface using eqns (2) and (3). These surface concentrations were then used in the analytical model (eqn (1)) to calculate the mass of solutes transferred from the soil to the runoff water. To our knowledge, this is the first application of such modelling in two-dimensions and represents a methodology that can be used in many other applications where the soil solute concentration will vary in a two- or three-dimensional manner. Such applications could be in runoff from urine or dung patches, fertigation from dripper irrigation or where fertilisers are applied in bands.

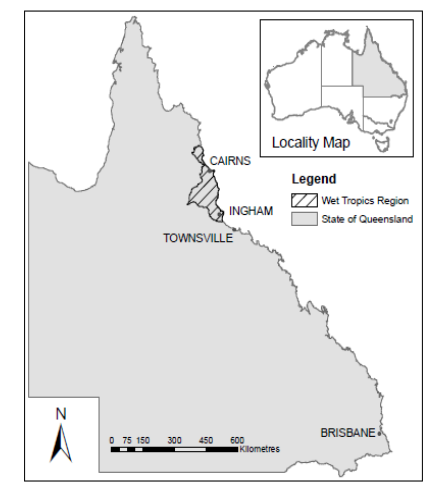

Figure 1. Location of site is $20 \mathrm{~km}$ north of Ingham in the wet tropics.

Table 2. Soil particle size distribution with the measured values defined according to the Australian standard

\begin{tabular}{|l|l|l|l|l|l|}
\hline \multicolumn{2}{|l|}{ Depth (m) } & \multicolumn{4}{l|}{ Australian classification } \\
\hline Upper & lower & $\begin{array}{l}\text { Coarse } \\
\text { sand } \\
(\%)\end{array}$ & $\begin{array}{l}\text { Fine } \\
\text { sand } \\
(\%)\end{array}$ & $\begin{array}{l}\text { Silt } \\
(\%)\end{array}$ & $\begin{array}{l}\text { Clay } \\
(\%)\end{array}$ \\
\hline 0 & 0.1 & 20 & 63.3 & 10.6 & 10.6 \\
\hline 0.2 & 0.3 & 21.8 & 62.1 & 12.3 & 8.8 \\
\hline 0.6 & 0.7 & 24.8 & 69.9 & 5.3 & 5.4 \\
\hline 0.8 & 0.9 & 5.6 & 65.6 & 13.8 & 20.7 \\
\hline 1.1 & 1.2 & 13.2 & 55.3 & 15.4 & 20.7 \\
\hline 1.4 & 1.5 & 2.5 & 64.4 & 15.4 & 22.4 \\
\hline
\end{tabular}

\section{METHODS}

\subsection{Site and Soil}

The trial was conducted in June and July 2014 at the Macknade Research Station, 20 km north of Ingham, Queensland (Figure 1). The site is located in the Wet Tropics with a long-term average annual rainfall of 2154 $\mathrm{mm}$

(http://www.bom.gov.au/jsp/ncc/cdio/weatherData/av?p_nccObsCode=139\&p_display type=dataFile\&p_sta rtYear $=\& p \quad c=\& p$ stn num $=032032)$. Two soils are present at the site; is a moderately well-drained Chromosol and a Dermosol with a fine sandy clay loam texture on an 0.8 to $1.0 \%$ slope (Table 2 ). 


\subsection{Experimental layout and treatments}

The plot-scale experiment was conducted using a rainfall simulator centred over a recently planted cane row in a minimum tillage paddock. The rainfall simulator is described in detail in Loch et al. (2001). The cane was planted in dual rows in semipermanent raised beds with a $1.8 \mathrm{~m}$ row spacing, with no fill-in practices applied. The soil was bare, as the planted cane stalks had barely grown during the experimental period, and untilled.

Each $1.7 \mathrm{~m}$ long by $1.0 \mathrm{~m}$ wide rainfall simulator plot is bounded by a 3-sided metal frame approximately $3 \mathrm{~mm}$ wide by $150 \mathrm{~mm}$ deep, installed 50 to $70 \mathrm{~mm}$ into the ground to provide a hydraulic barrier around the edge (Elledge et al., 2016). The down-slope end of the plot has a metal plot-front installed which includes a spout to collect runoff.

Simulated rainfall was applied on three fertiliser treatments (nil fertiliser, sub-surface and surface) at a mean intensity of $87 \mathrm{~mm} / \mathrm{h}$ until runoff commenced. This rainfall rate is similar to the 100 year 30 minute rainfall rate. The period of time the rainfall simulation occurred for varied as application of rainfall continued until 30 minutes of runoff had occurred. During the runoff event, a composite sample was collected by sampling 5 seconds of runoff at 0 minutes (time at which runoff commenced), then at 5 minute intervals after this up to 30 minutes after runoff commenced.

Granular fertiliser (Nitrophoska Special: 12\% nitrogen, $5.2 \%$ phosphorous, $14.1 \%$ potassium and $8 \%$ sulphur) was applied on the surface and subsurface at $385.5 \mathrm{~kg} / \mathrm{ha}(46 \mathrm{~kg} / \mathrm{ha} \mathrm{N} ; 54 \mathrm{~kg} / \mathrm{ha} \mathrm{K}$; $20 \mathrm{~kg} / \mathrm{ha} \mathrm{P}$ ) immediately after planting.

Simulated rainfall was applied at three times, 7, 20 and 55 days after fertilisation. For surface and subsurface fertilised two plots had simulated irrigation applied to them on all three times, two plots two times and two plots only once (Table 2). The nil fertiliser treatment plots did not have any plots where repeated rainfall simulations were carried out (Table 2).
Table 3. Day of simulated rainfall application and amount of prior rainfall on each plot. $\mathrm{N}$ indicates no simulated rainfall.

\begin{tabular}{|c|c|c|c|c|}
\hline \multirow[t]{3}{*}{$\begin{array}{l}\text { Fertiliser } \\
\text { Treatment }\end{array}$} & \multirow[t]{3}{*}{ Plot no. } & \multicolumn{3}{|c|}{$\begin{array}{l}\text { Day of Simulated } \\
\text { Rainfall (DAF) }\end{array}$} \\
\hline & & 7 & 20 & 55 \\
\hline & & \multicolumn{3}{|c|}{$\begin{array}{l}\text { Prior simulated } \\
\text { rainfall added }(\mathrm{mm})\end{array}$} \\
\hline \multirow[t]{6}{*}{ Surface } & 1 & 0 & 55 & 110 \\
\hline & 4 & $\mathrm{~N}$ & 0 & 55 \\
\hline & 7 & $\mathrm{~N}$ & $\mathrm{~N}$ & 0 \\
\hline & 10 & 0 & 55 & 110 \\
\hline & 13 & $\mathrm{~N}$ & 0 & 55 \\
\hline & 16 & $\mathrm{~N}$ & $\mathrm{~N}$ & 0 \\
\hline \multirow[t]{6}{*}{ Subsurface } & 2 & 0 & 55 & 110 \\
\hline & 5 & $\mathrm{~N}$ & 0 & 55 \\
\hline & 8 & $\mathrm{~N}$ & $\mathrm{~N}$ & 0 \\
\hline & 11 & 0 & 55 & 110 \\
\hline & 14 & $\mathrm{~N}$ & 0 & 55 \\
\hline & 17 & $\mathrm{~N}$ & $\mathrm{~N}$ & 0 \\
\hline \multirow[t]{6}{*}{ Nil } & 3 & 0 & $\mathrm{~N}$ & $\mathrm{~N}$ \\
\hline & 6 & $\mathrm{~N}$ & 0 & $\mathrm{~N}$ \\
\hline & 9 & $\mathrm{~N}$ & $\mathrm{~N}$ & 0 \\
\hline & 12 & 0 & $\mathrm{~N}$ & $\mathrm{~N}$ \\
\hline & 15 & $\mathrm{~N}$ & 0 & $\mathrm{~N}$ \\
\hline & 18 & $\mathrm{~N}$ & $\mathrm{~N}$ & 0 \\
\hline
\end{tabular}




\subsection{Estimation of model parameters}

All the soil physical properties in Table 3 were estimated using the data in Table 2 plus bulk density data using the pedotransfer methods of Cook and Cresswell (2008). These values along with estimates of: the reaction rates for the nitrogen chain reaction of ammonium to nitrite to nitrate which is available in HYDRUS2D (Radcliffe and Simunek, 2010); the adsorption coefficient (Kd) for ammonium $\left(\mathrm{NH}_{4}-\mathrm{N}\right)$ (estimated using Vogeler et al. 2011); and the diffusion coefficients, were used to simulate the nitrogen lost in runoff. The final values of the soil physical properties reaction rates and $\mathrm{Kds}$ for each of the three layers used in the modelling are given in Table 4.

The plots were covered between simulations which would have reduced the evaporation. It was found that adjusting this to a value of
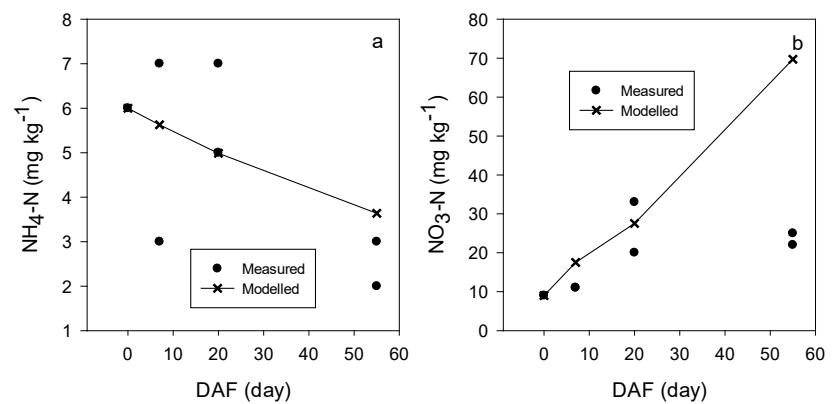

Figure 2. Measured and modelled concentration of a) ammonium $\left(\mathrm{NH}_{4}-\mathrm{N}\right)$ and $\left.\mathrm{b}\right)$ nitrate $\left(\mathrm{NO}_{3}-\mathrm{N}\right)$ nitrogen in the soil with days after fertilisation (DAF). $0.25 \mathrm{PET}$ (PET is the potential evaporation
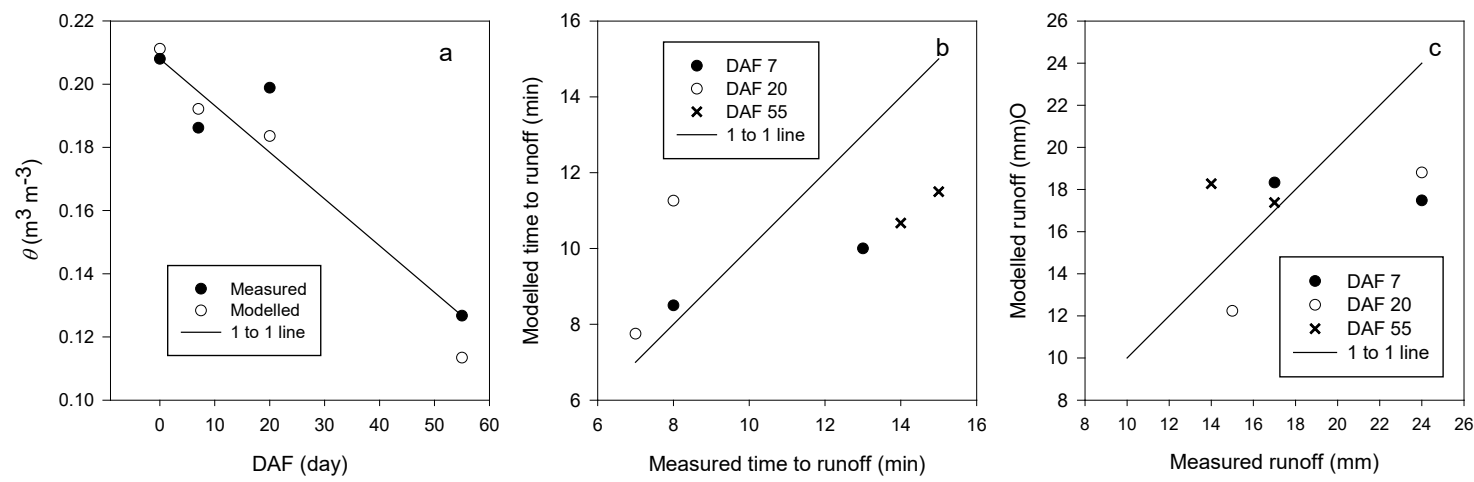

Figure 3. Measured and modelled: a) soil water content, b) time to runoff and c) runoff depth. The data is shown with days after fertilisation (DAF) indicated by the symbols.

rate) resulted in keeping the soil nitrate concentrations close to the measured values (figure 2). The values were then adjusted to give the best fit to soil nitrogen concentrations (figure 2), soil water content, time to runoff and runoff depth (figure 3 ) and $\mathrm{NH}_{4}-\mathrm{N}$ and $\mathrm{NO}_{\mathrm{x}}-\mathrm{N}$ in runoff (not shown). The mean transfer coefficient in Table 4 were used for modelling the nitrogen transfer to the runoff water for the subsurface and surface-applied fertiliser. The value of $0.015 \mathrm{~cm} \mathrm{day}^{-1}$ is very similar to the value for bromide of $0.0138 \mathrm{~cm} \mathrm{day}^{-1}$ found by Wallach and van Genuchten (1990).

Analysis of the data (Cook et al. in prep) had shown that the plots receiving successive rainfall simulations, the infiltration rate decreased by half after the first rainfall simulation. Thus, simulations were carried out with the saturated hydraulic conductivity (Ks) of layer 1 halved.

\section{RESULTS AND DISCUSSION}
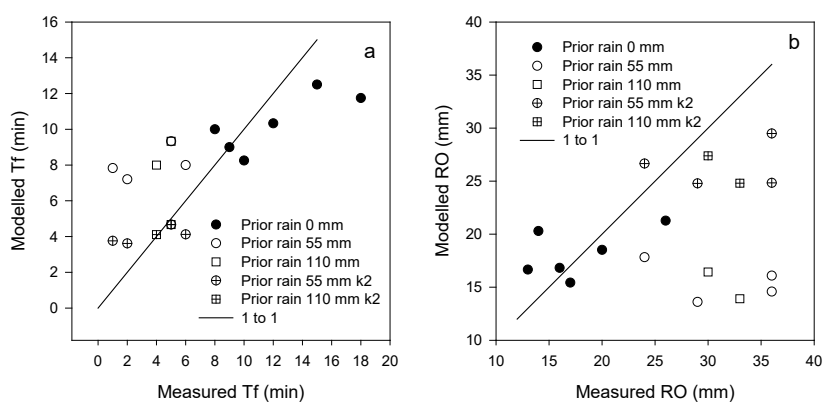

Figure 4. Plots of measured versus modelled a) time to runoff (Tf) and b) runoff depth (RO) from plots that received subsurface fertiliser. The results are plotted so that the effect of prior rainfall can be discerned. Results are also shown for plots which received a second rainfall event (prior rain $55 \mathrm{~mm}$ ) and third rainfall event (prior rain 110 $\mathrm{mm}$ ) with the Ks of layer 1 halved.

The hybrid model was used to simulate the dissolved nitrogen components $\left(\mathrm{NH}_{4}-\mathrm{N}\right.$ and $\left.\mathrm{NO}_{\mathrm{x}}-\mathrm{N}\right)$ in runoff for the subsoil and surface applied fertiliser. This is most likely due to modification of the soil structure at the surface. 


\subsection{Subsurface fertiliser treatment}

When modelling the subsurface fertiliser treatment, only half the bed had to be modelled as the fertiliser was placed in the middle of the bed. The initial concentration was estimated by assuming that the fertiliser was mixed into the soil in a band $0.02 \mathrm{~m}$ wide and $0.1 \mathrm{~m}$ deep, 1 in the soil profile between 0.05 and $0.15 \mathrm{~m}$. The results show that the time to runoff generation (Tf) and runoff volume was modelled well by the simulation (figure 4), especially when the Ks of layer 1 was halved following the first rainfall simulation. The root mean square of the error (RMSE) for modelled Tf and RO were $4.10 \mathrm{~min}$ and $4.7 \mathrm{~mm}$ respectively, and refined index of agreement (dr, (Wilmott et al. 2012), $\mathrm{dr}=1$ is a perfect model and the range of $\mathrm{dr}$ is from 1 to -1$) 0.56$ and 0.71 respectively, which indicated that the runoff timing and depth was modelled well by HYDRUS2D. The $\mathrm{NH}_{4}-\mathrm{N}$ mass lost to the runoff water was generally underestimated,
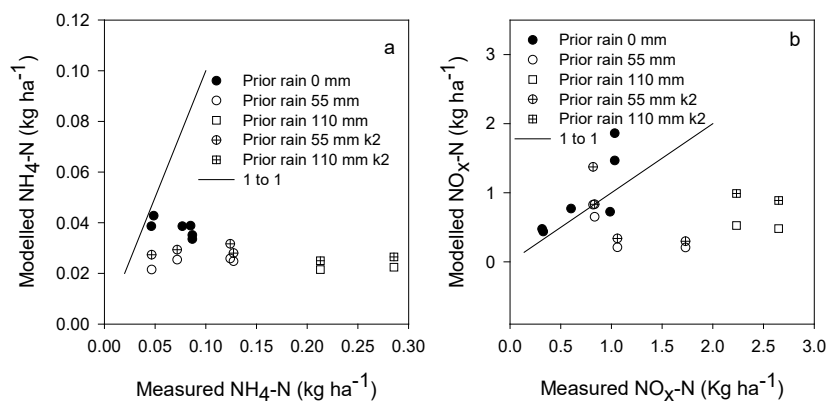

Figure 5. Plots of measured versus modelled a) $\mathrm{NH}_{4}-\mathrm{N}$ and b) nitrate plus nitrite $\left(\mathrm{NO}_{\mathrm{x}}-\mathrm{N}\right)$ from plots that received subsurface fertiliser. The results are plotted so that the effect of prior rainfall can be discerned. Results are also show for plots which received a second rainfall event (prior rain 55 $\mathrm{mm}$ ) and third rainfall event (prior rain $110 \mathrm{~mm}$ ) with the Ks of layer 1 halved.

although halving the Ks of layer 1 did increase the modelled $\mathrm{NH}_{4}-\mathrm{N}$ for plots receiving a second and third rainfall simulation (figure 5a). The $\mathrm{NO}_{\mathrm{x}}-\mathrm{N}$ was much better modelled but even with halving the Ks of layer 1 , the $\mathrm{NO}_{\mathrm{x}}-\mathrm{N}$ in the runoff for second and third rainfall simulations was less than the measured values (figure 5b). The RMSE was 0.13 and $1.45 \mathrm{~kg}-\mathrm{N} \mathrm{ha} \mathrm{yr}^{-1}$ for $\mathrm{NH}_{4}-\mathrm{N}$ and $\mathrm{NO}_{\mathrm{x}}-\mathrm{N}$ respectively with the half $\mathrm{Ks}$ values for second and third rainfall simulations. The dr was 0.27 and 0.52 for $\mathrm{NH}_{4}-\mathrm{N}$ and $\mathrm{NO}_{\mathrm{x}}-\mathrm{N}$ respectively with the half $\mathrm{Ks}$ values for second and third rainfall simulations, which means $\mathrm{NO}_{\mathrm{x}}-\mathrm{N}$ is better predicted with the model than $\mathrm{NH}_{4}-\mathrm{N}$.

Table 3. Soil physical properties for soil layers used in the HYDRUS2D simulations: residual and saturated volumetric water contents $\left(\theta_{\mathrm{r}}\right.$ and $\left.\theta_{\mathrm{s}}\right)$, scaling parameter $(\alpha)$, scaling parameter (n), saturated hydraulic conductivity $(\mathrm{Ks})$, hydraulic conductivity scaling parameter (l) and adsorption coefficient $(\mathrm{Kd})$ for $\mathrm{NH}_{4}-\mathrm{N}$. The molecular diffusion coefficients for nitrogen species in water (D). The mean and standard error for the transfer coefficient $(\mathrm{k})$ is shown for $\mathrm{NH}_{4}-\mathrm{N}$ and $\mathrm{NO}_{\mathrm{x}}-\mathrm{N}$

\begin{tabular}{|l|l|l|l|l|l|l|l|l|}
\hline Layer & $\begin{array}{l}\text { Depth } \\
\text { range }(\mathrm{m})\end{array}$ & $\theta_{\mathrm{r}}$ & $\theta_{\mathrm{s}}$ & $\begin{array}{l}\alpha \\
\left(\mathrm{m}^{-1}\right)\end{array}$ & $\mathrm{n}$ & $\begin{array}{l}\mathrm{Ks} \\
\left(\mathrm{m} \mathrm{s}^{-1}\right)\end{array}$ & 1 & $\begin{array}{l}\mathrm{Kd} \\
\left(\mathrm{m}^{3} \mathrm{~kg}^{-1}\right)\end{array}$ \\
\hline 1 & $0-0.25$ & 0 & 0.600 & 6.50 & 1.650 & $1.08 \times 10^{-5}$ & -1.02 & 40.3 \\
\hline 2 & $0.25-0.50$ & 0.056 & 0.411 & 3.07 & 1.487 & $8.65 \times 10^{-6}$ & 1.36 & 34 \\
\hline 3 & $0.50-0.75$ & 0.043 & 0.369 & 4.39 & 1.100 & $1.16 \times 10^{-6}$ & 0.5 & 53 \\
\hline $\begin{array}{l}\mathrm{N} \\
\text { species }\end{array}$ & $\begin{array}{l}\mathrm{D} \\
\left(\mathrm{m}^{2} \mathrm{~s}^{-1}\right)\end{array}$ & $\begin{array}{l}\mathrm{k} \\
\left(\mathrm{cm} \mathrm{day}{ }^{-1}\right)\end{array}$ & & & & & & \\
\hline $\mathrm{NH}_{4}$ & $1.957 \times 10^{-9}$ & $0.20 \pm 0.04$ & & & & & & \\
\hline $\mathrm{NO}_{2}$ & $1.912 \times 10^{-9}$ & & & & & & & \\
\hline $\mathrm{NO}_{3}$ & $1.902 \times 10^{-9}$ & & & & & & & \\
\hline $\mathrm{NO}_{\mathrm{x}}$ & & $0.015 \pm 0.003$ & & & & & & \\
\hline
\end{tabular}

\subsection{Surface fertiliser treatment}

The surface fertiliser was applied in a band $100 \mathrm{~mm}$ wide to one side of the centre line of the bed. This meant that the whole of the bed had to be modelled in order to properly represent the experiment. The fertiliser was assumed to be mixed into a depth of $0.01 \mathrm{~m}$. Similar to the subsurface fertiliser treatment, simulations of the time to runoff and runoff depth was modelled well by the HYDRUS2D model with the estimated parameters (figure 6), especially when the Ks of layer 1 was halved for plots where second and third rainfalls occurred. The model was able to both fit time to runoff with an RMSE of $4.6 \mathrm{~min}$ and $\mathrm{dr}$ of 0.77 and the runoff depth 
with and RMSE of $13.3 \mathrm{~mm}$ and dr of 0.83 well when values from plots with Ks of layer 1 were used for second and third rainfall simulations on plots.

The modelled $\mathrm{NH}_{4}-\mathrm{N}$ in runoff for the surface-applied fertiliser was generally greater than the measured values (figure 7a). The modelled $\mathrm{NO}_{x}-\mathrm{N}$ in the runoff was also greater than the measured values for plots where only a single rainfall simulation occurred while plots that had second and third rainfall simulations had modelled NOx-N values less than the measured values (figure $7 b$ ). Halving the Ks of layer 1 exacerbates the difference between measured and modelled for $\mathrm{NH}_{4}-\mathrm{N}$ but decreased the difference for $\mathrm{NO}_{\mathrm{x}}-\mathrm{N}$. The RMSE and $\mathrm{dr}$ for $\mathrm{NH}_{4}-\mathrm{N}$ mass loss rate were $0.51 \mathrm{~kg}-\mathrm{N}$ $\mathrm{ha}^{-1} \mathrm{yr}^{-1}$ and 0.34 for the data with $\mathrm{Ks}$ halved for layer 1 when second and third rainfall simulations occurred. The RMSE and dr of NOx-N $1.07 \mathrm{~kg}-\mathrm{N} \mathrm{ha} \mathrm{h}^{-1} \mathrm{yr}^{-1}$ and 0.43 indicated that the model fitted the NOx-N data better.

\section{CONCLUSION}

The modelling of runoff losses of surface and subsurface-applied fertiliser showed
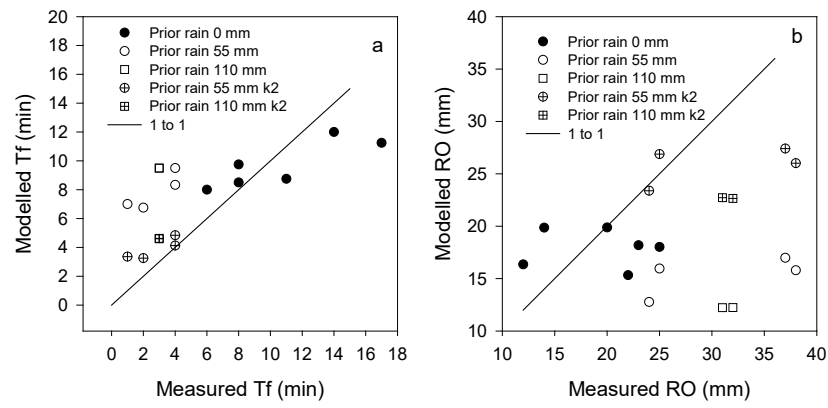

Figure 6. Comparison of measured and modelled: a) time to runoff (Tf) and b) runoff depth (RO) for the surface applied fertiliser plots. The data is plotted to show the effect of prior rainfall on the plots. The plots which received second and third rainfall simulations (55 and $110 \mathrm{~mm}$ of prior rainfall) had simulations with Ks of layer 1 reduced by half and are shown with $\mathrm{k} 2$ in the legend.

that the HYDRUS2D model was able to model the time to runoff and runoff depth well, which would indicate that the physical parameters are applicable for this soil. These parameters would be suitable for doing further modelling of water transport for this site.

The modelling of the nitrogen transfer to the runoff indicated that the subsurface-applied fertiliser model generally underestimates $\mathrm{NH}_{4}-\mathrm{N}$ but gets the nitrate approximately correct. For the surface-applied fertiliser model, the $\mathrm{NH}_{4}-\mathrm{N}$ and $\mathrm{NO}_{\mathrm{x}}-\mathrm{N}$ is generally overestimated. However, the modelled values are well within one order of magnitude of the measured values, which given the uncertainty in the model parameters is encouraging.

Given the difficulties with modelling solute transport these results are encouraging. This hybrid modelling approach is promising
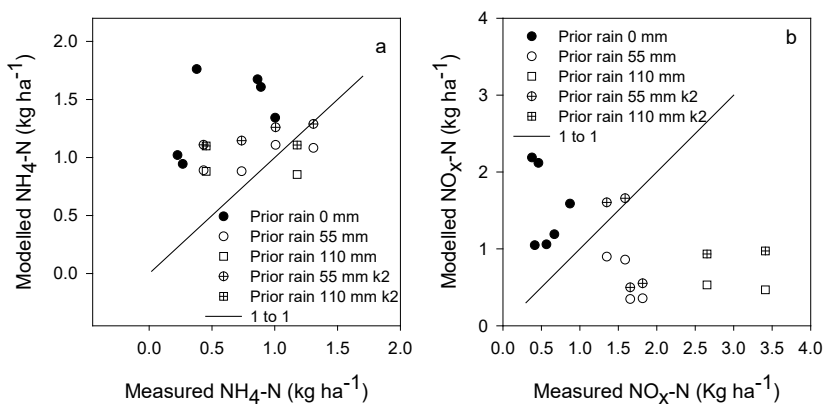

Figure 7. Comparison of measured and modelled: a) $\mathrm{NH}_{4}-$ $\mathrm{N}$ and $\mathrm{b}$ ) nitrogen oxides $\left(\mathrm{NO}_{\mathrm{x}}-\mathrm{N}\right)$ for the surface applied fertiliser plots. The data is plotted to show the effect of prior rainfall on the plots. The plots which received second and third rainfall simulations (55 and $110 \mathrm{~mm}$ of prior rainfall) had simulations with Ks of layer 1 reduced by halve and are shown with $\mathrm{k} 2$ in the legend.

and should be further developed. This modelling approach will allow for better estimates of nutrient mass in runoff and lead to improved water quality.

\section{ACKNOWLEDGEMENTS}

The senior author would like to thank the Queensland Department of Natural Resources Mines and Energy for funding him to develop this model. The experimental work this paper is based on and the funding of this work received support from the Australian and Queensland governments' Paddock to Reef program.

\section{REFERENCES}

Cook, F.J., Cresswell, H.P. (2007). Chapter 84 Estimation of Soil Hydraulic Properties. In Soil Sampling and Methods of Analysis. M.R. Carter and E.G. Gregorich (Eds.), Canadian Society of Soil Science, Taylor and Francis, LLC, Boca Raton, Fl, 1139-1161. 
Cook, F.J., Cowie, B., Turner, R., Silburn, D.M., Eyles, M., Bosomworth, B. (2019). Rainfall induced runoff of nitrogen and phosphorus from recently fertilised beds: 1. Measurements and results. Agriculture Environment and Ecosystems (In prep.).

Cowie, B.A., DiBella L.P., Davison, L.K., Tang, W.W., Benson, A.J., Poggio, M. (2013). Sub-surface fertiliser application in sugar cane: Reduced runoff loss under simulated rainfall seven days after application. Paper Ag 16, Australian Society for Sugar Cane Technology Conference.

D’Angelo, C., Wiedenmann, J. (2014). Impacts of nutrient enrichment on coral reefs: new perspectives and implications for coastal management and reef survival. Current Opinion in Environmental Sustainability 7 , pp. 82-93.

Elledge, A., Cowie, B., Wallace, S. (2016). Simulated rainfall trials to quantify management practices that reduce dissolved inorganic nitrogen and sediment in runoff from plant sugarcane in the Herbert catchment, Wet Tropics. Report of the Herbert Cane Productivity Services Limited, Department of Natural Resources and Mines, Rockhampton p.18.

Harris, G.P. (2001). Biogeochemistry of nitrogen and phosphorus in Australian catchments, river and estuaries: effects of land use and flow regulation and comparisons with global patterns. Marine and Freshwater

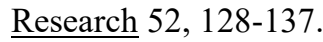

Loch, R.J., Robotham, B.G., Zeller, L., Masterman, N, Orange, D.N., Bridge, B.J. Sheridan, G., Bourke, J.J. (2001). A multi-purpose rainfall simulator for field infiltration and erosion studies. Australian Journal of Soil Research, 39, 599-610.

Melland, A.R., Cowie, B., Silburn, D.M., Eyles, M. (2019). Impacts of sugarcane management practices on nitrogen runoff in the wet tropics of Queensland, Australia. Journal of Environmental Management (In prep.).

Radcliffe, D.E., Simunek, J. (2010) Soil Physics with HYDRUS: Modelling and Applications. CRC Press, Taylor and Francis, Boca Raton, 372p.

Simunek J., van Genuchten M. Th., Šenja M., (2012). The HYDRUS software package for simulating twoand three dimensional movement of water, heat and multiple solutes in variably-saturated porous media. Version 2.0, Technical Manual, PC Progress, Prague, Czech Republic, 258p.

Vogeler, L., Cichota, R., Snow, V.O., Dutton, T., Daly, B. (2011). Pedotransfer functions for estimating ammonia adsorption in soils. Soil Science Society of America Journal, 75, 324-331.

Wallach, R., van Genuchten, M. Th. (1990). A physically based model for predicting solute transfer from soil solution to rainfall-induced runoff water. Water Resources Research 26, 2119-2126.

Waterhouse, J., Brodie, J., Lewis, S., Mitchell A. (2012). Quantifying the sources of pollutants in the Great Barrier Reef catchments and the relative risk to reef ecosystems. Marine Pollution Bulletin 65, 394-406.

Wilmott, C.J., Robeson, S.M., Matsuura, K. (2012). A refined index of model performance. International Journal of Climatology 32, 2088-2094.

Wooldridge, S., Brodie, J., Furnas M. (2006). Exposure of inner-reefs to nutrient enriched runoff entering the Great Barrier Reef Lagoon: Post-European changes and the design of water quality targets. Marine Pollution Bulletin 52 1467-1479. 